\title{
Identificación e implementación de paquetes tecnológicos en ganadería vacuna de doble propósito. Caso Manabí-Ecuador
}

\section{Identification and implementation of technological packages for dual purpose cattle. A case study of Manabí-Ecuador}

\author{
Yenny Torresa, J osé Rivasb, Carmen De Pablos-Herederoc, J osé Peread, Paula Toro- \\ Mujicae, Elena Angónd, Antón Garcíad
}

\begin{abstract}
RESUMEN
El avance en los sistemas ganaderos se asocia a la implementación de tecnologías en la producción y a la mejora de sus ingresos. El objetivo del presente estudio fue la identificación e implementación de paquetes tecnológicos y su relación con los resultados productivos en vacuno de doble propósito de la provincia de Manabí, Ecuador en dos zonas climáticas: el Bosque seco tropical y el húmedo tropical. Se agrupan 25 tecnologías en seis paquetes tecnológicos (PT) seleccionadas mediante una metodología cualitativa y participativa. Se realizaron entrevistas en una muestra de 41 explotaciones para evaluar la implementación de los paquetes tecnológicos, mediante estadística descriptiva, correlaciones de Sperman y regresiones múltiples. Se obtienen los mayores niveles de implementación en los paquetes de salud animal (76\%), uso de la tierra y alimentación (55\%). El PT de alimentación se correlaciona (P<0.01) con el PT de instalaciones (0.711) y de reproducción (0.774). Los PT explican $30 \%$ de la variabilidad de la producción de leche, que es debida al uso de la tierra en el Bosque seco y a la salud animal en el Bosque húmedo. Esta investigación genera resultados preliminares respecto a la idententificación e implementación de los principales paquetes tecnológicos en la ganadería vacuna de doble propósito de Manabí - Ecuador, que están en proceso de mejora aunque sin perder los atributos que lo caracterizan.
\end{abstract}

PALABRAS CLAVE: Paquetes tecnológicos, Doble propósito.

\begin{abstract}
Advances in livestock systems are associated with the implementation of technologies in production and improvment of their income.The aim of this research was to examine the identification and implementation of technological packages and their relationship with the variability of the production in the dual purpose cattle of Manabí - Ecuador. Two climatic zones are distinguished: 1) Tropical dry forest and 2) Tropical rain forest. Twenty five (25) technologies grouped into six technological packages (TP) were selected by using qualitative and participatory methods. Interviews were conducted in a sample of $\mathbf{4 1}$ farms to assess the implementation of technological packages, using descriptive statistics, Sperman correlations and multiple regressions. The higher degrees of implementation correspond to animal health $(76.2 \%)$, equipment $(55.6 \%)$ and feeding $(55.5 \%)$. Correlations $(P<0.01)$ between TP of feeding, with equipment $(0.711)$ and reproduction $(0.774)$ were evidenced. The variability in milk production (30 \%) is explained by the TP of land use in the Tropical dry Forest and by the TP animal health in Tropical rain forest. This research facilitates preliminary results about the identification of a number of technologies that are implemented in the dual purpose cattle of Manabí - Ecuador. Moreover, all animal production systems being seeking a dynamic balance of technologies that allows farms migrate to more efficient processes without losing the main attributes, in this case of the dual purpose cattle systems.
\end{abstract}

KEY WORDS: Technological packages, Dual purpose cattle.

Recibido el 27 de marzo de 2014. Aceptado el 8 de mayo de 2014

a Universidad Técnica Estatal de Quevedo. Campus Ing. Manuel Haz Álvarez. Quevedo, Los Ríos, Ecuador.

b Universidad Central de Venezuela. Maracay, Venezuela.

Universidad Rey Juan Carlos. Madrid, España.

d Universidad de Córdoba, Campus de Rabanales, Córdoba, España. Economía Agraria. Crta. Madrid-Cádiz, km 397. Código postal 14014. Teléfono: 0034957218745. Córdoba, España. palgamaa@uco.es. Correspondencia al último autor.

e Pontificia Universidad Católica de Chile. Santiago. Chile. 


\section{INTRODUCCIÓN}

El sector bovino lechero adquiere gran importancia estratégica en Ecuador, con una producción diaria de 5.8 millones de litros y ocupando al $8 \%$ de la población activa. La producción lechera se concentra principalmente en tres zonas geográficas: 1) La Sierra (77 \%), con clima templado y modelo intensivo especializado, 2) La Costa (15\%) y 3) Amazonía $(8 \%)$, ambas con clima cálido y un modelo productivo de ganadería vacuna de doble propósito(1,2).

Para potenciar la mejora de los ingresos en las explotaciones familiares se requieren cambios tanto en la adopción de nuevas tecnologías, como en la organización de la explotación. En otras latitudes, los cambios realizados se han orientado principalmente al campo de la salud animal y calidad de la leche, el sistema de alimentación, la mecanización de los procesos y la mejora reproductiva y genética(3,4). La incorporación de nuevas tecnologías conlleva la identificación, adopción e implementación de la tecnología por un lado y su difusión en el corto y mediano plazo por otro. La implementación tecnológica constituye un proceso complejo, resultante de la adecuación dinámica de distintos factores dentro de la explotación y en un contexto económico, social y cultural donde coexisten productores que la adoptan de modo temprano, en tanto que los rezagados retrasan su implementación(5).

La mejora de los ingresos se asocia directamente al nivel tecnológico utilizado, por lo que su implementación, efecto e impacto en la producción constituyen eventos claves que favorecen la competitividad del sector(6). En una primera fase es necesario identificar las tecnologías incorporadas, la secuencia de incorporación y el modo de hacerlo(5), para posteriormente evaluar su impacto; ya que la tecnología constituye un recurso que complementado con otros recursos humanos y organizativos afloran capacidades dinámicas y mejoran el posicionamiento estratégico de la explotación(6).

\section{INTRODUCTION}

The dairy cattle industry has acquired great strategic importance in Ecuador, with a daily production of 5.8 million liters and using an $8 \%$ of the workforce. The dairy production is mainly concentrated in three geographic areas: 1) mountain ( $77 \%)$, with mild climate and intensive specialized model, 2) coast (15\%) and 3) Amazonia ( $8 \%$ ), both characterized by warm weather and the establishment of a dualpurpose cattle production model( $(1,2)$.

To promote the improvement of income in family farms changes, both in the adoption of new technologies, as well as in the organization of the farm are required. In other latitudes, changes have mainly been oriented to the field of animal health, quality of the milk, the system for feeding, the mechanization of processes and reproductive and genetic improvement $(3,4)$. The incorporation of new technologies involves the identification, adoption and implementation of the technology and its diffusion in the short and medium-term. The implementation of technology is a complex process, resulting from the dynamic adaptation of various factors within the farm, and also the economic, social and cultural context where producers who adopt it early coexist with that latecomers that delay its implementation(5).

The improvement of revenues is directly associated with the technological level used, so its implementation, effect and impact on production are key events that promote the competitiveness of the Sector(6). In a first phase, it is necessary to identify the incorporated technologies, the sequence of incorporation and how to do it(5), to subsequently assess their impact; since technology is a resource that complemented with other human and organizational resources, produces dynamic capabilities and improve the strategic positioning of the farm(6).

The objective of this study was to analyze the implementation of technologies, deepen the 
El objetivo de este trabajo es analizar la implementación de tecnologías, profundizar en el conocimiento del patrón de uso de la tecnología por la ganadería vacuna de doble propósito y su relación con la variación de los resultados productivos. Finalmente se plantean las perspectivas tecnológicas de la ganadería de la Provincia de Manabí en la Costa Ecuatoriana.

\section{MATERIALES Y MÉTODOS}

Marco conceptual

La innovación tecnológica comprende el conjunto de actividades científicas, tecnológicas, financieras y comerciales que permiten mejorar productos, servicios, procesos, técnicas de gerencia y sistemas organizacionales $(7,8)$. La implementación de tecnologías comienza con la identificación de variables tecnológicas y el modo de valorarlas. La identificación de tecnologías y su agrupación en paquetes determina distintos resultados al depender de factores técnicos, sociales, económicos y políticos de la explotación. Por otra parte, deben buscarse paquetes tecnológicos relevantes para los usuarios, de fácil obtención y comprensión, dinámicos, fáciles de implementar y sensibles a las necesidades de los usuarios(8).

\section{PAQUETES TECNOLÓGICOS}

La construcción de los paquetes tecnológicos se realiza en seis etapas (Figura 1).

Etapa 1. Selección de tecnologías

A partir de la revisión bibliográfica $(4,6,9,10)$ se seleccionaron 64 variables representativas de las diferentes tecnologías existentes en los sistema de ganadería vacuna de doble propósito concentradas en la costa Ecuatoriana.

Etapa 2. Paquetes tecnológicos

Se aplicó una metodología de carácter cualitativo y participativo, que valora de modo directo la adopción de las nuevas tecnologías(5). Identificadas las innovaciones tecnológicas se presentan al grupo de trabajo de 14 expertos, knowledge of the pattern of use of technology by the dual purpose livestock and its relation with the variation of the productive results. Finally, raise the technological prospects of livestock in the province of Manabí on the Ecuadorian coast.

\section{MATERIALS AND METHODS}

Conceptual framework

Technological innovation includes the set of scientific, technological, financial and commercial activities that allow to improve products, services, processes, management techniques and organizational systems $(7,8)$. The implementation of technology begins with the identification of technological variables and how to assess them. The identification of technologies and their

Figura 1. Marco conceptual en el desarrollo de paquetes tecnológicos

Figure 1. Conceptual frame for the development of the technological packages

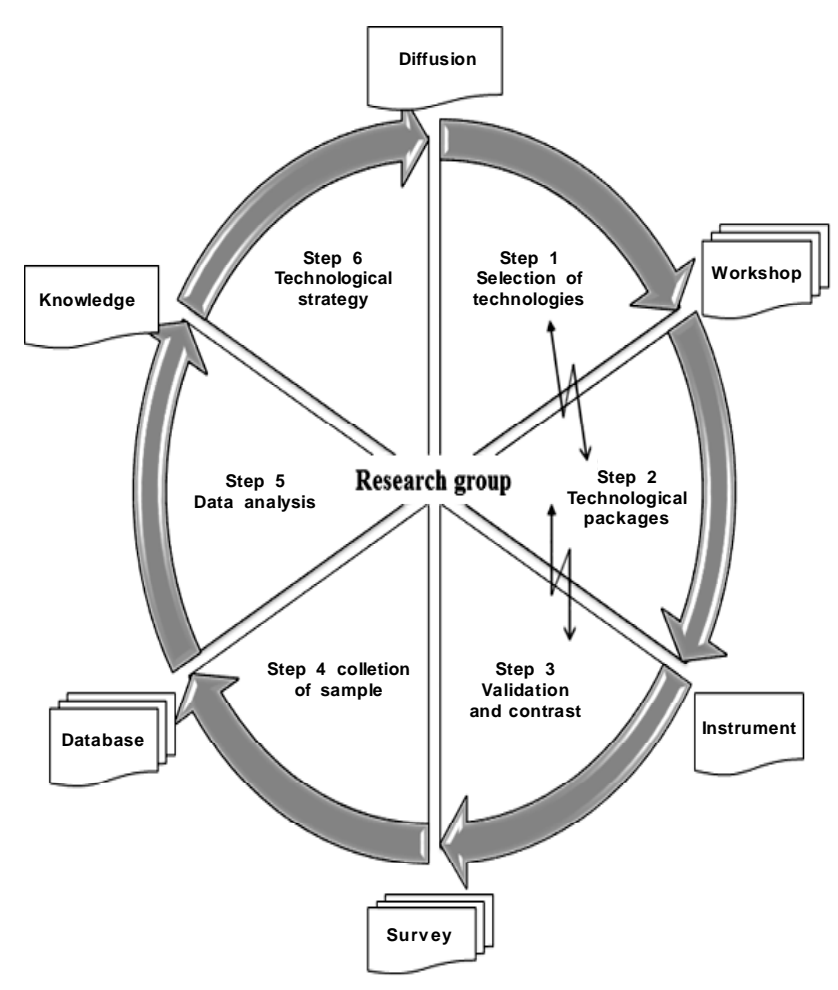


compuesto por seis profesores de universidad, cuatro investigadores, dos técnicos de extensión y un asesor independiente en pastos y alimentación y reproducción, que proceden a la selección y agrupación en paquetes tecnológicos (PT).

Incialmente se seleccionaron aquellas tecnologías que recibieron la máxima puntuación por cinco o más miembros del grupo de expertos. En una segunda vuelta se debatió la incorporación de aquellas variables dudosas con cuatro puntuaciones máximas, para finalmente obtener 25 tecnologías seleccionadas en los seis PT identificados (Anexo 1).

Etapa 3. Validación y contraste de paquetes tecnológicos

La propuesta de PT se ajustó a un cuestionario que fué validado mediante su aplicación en una explotación piloto, y la posterior retroalimentación que posibilitó generar el cuestionario definitivo.

Etapa 4. Recogida de información. Caso de Manabí.

La provincia de Manabí se ubica en la costa ecuatoriana con una superficie de $19,364 \mathrm{~km}^{2}$. Se extiende a ambos lados de la línea equinoccial, de $0^{\circ} 25^{\prime} \mathrm{N}$ hasta $1^{\circ} 57^{\prime} \mathrm{S}$, y de $79^{\circ} 24^{\prime} \mathrm{O}$ a $80^{\circ}$ $55^{\prime}$ O. Se distinguen dos zonas agroecológicas: 1) Bosque seco tropical, caracterizado por alturas hasta de $300 \mathrm{msnm}$, temperatura media anual entre 23 a $25^{\circ} \mathrm{C}$, períodos de lluvia de diciembre a mayo de 1,000 a 2,000 $\mathrm{mm}$ y período seco de junio a noviembre; y 2) Bosque húmedo tropical, con alturas de 5 a $600 \mathrm{msnm}$, temperaturas promedio anual de 23 a $25.5{ }^{\circ} \mathrm{C}$, precipitaciones anuales de 2,000 a $3,000 \mathrm{~mm}$, con un período menos lluvioso de diciembre a febrero(2).

Se utilizó un diseño de muestreo aleatorio estratificado por zona agroecológica con asignación proporcional(10). Se estudiaron 41 explotaciones, lo que equivale al $3 \%$ de la población. La información de las tecnologías se obtuvo mediante visitas a las explotaciones y entrevistas in situ por el mismo técnico, durante el ejercicio 2012. grouping into packages determines different results depending upon technical, social, economic and political factors of the farm. On the other hand, technological packages relevant for users should be sought, easy to obtain and understand, dynamic, easy-to-implement and sensitive to the needs of the users( 8$)$.

\section{TECHNOLOGICAL PACKAGES}

The construction of the technological packages is carried out in six stages (Figure 1).

Stage 1. Selection of technologies

From the literature review $(4,6,9,10) 64$ variables were selected representing the different existing technologies in the of dual purpose cattle system, concentrated on the Ecuadorian coast.

\section{Stage 2. Technological packages}

A qualitative and participatory methodology that values the adoption of new technologies in a direct way was applied(5). The technological innovations identified were presented to the Working Group of 14 experts, composed by six University professors, four researchers, two extension technicians and an independent assessor in pastures, feed and reproduction that selected and grouped them in technological packages (TP).

Initially, the technologies that received the highest score by five or more members of the Group of experts were selected. In a second round the incorporation of those dubious variables with the four highest scores was discussed, to finally obtain 25 technologies selected in the six TP identified (Annex 1).

Stage 3. Validation and contrast of technological packages

The proposal of each TP was adjusted to a questionnaire which was validated by its application in a pilot farm, and the subsequent feedback made it possible to generate the final questionnaire. 
Etapa 5. Análisis de datos

Inicialmente se realizó un inventario de las tecnologías y se cuantificó el nivel de uso de los seis PT. Posteriormente se determinó el grado de asociación entre los PT aplicando los coeficientes de correlación de Spearman. Asimismo se profundizó en la explicación de la variación de los resultados productivos como consecuencia del uso de los PT mediante regresión múltiple paso a paso(8).

Etapa 6. Estrategia Tecnológica. Retos de futuro

Se analizó el uso de las tecnologías, las razones de éxito y fracaso. Posteriormente, a tenor del entorno interno y externo de la explotación, y el análisis de tecnologías identificadas, se hizo una propuesta operativa de las tecnologías a incorporar para mejorar el posicionamiento competitivo de las explotaciones(8).

\section{RESULTADOS Y DISCUSIÓN}

El vacuno en la Costa responde a un sistema mixto de agricultura con ganadería de doble propósito de baja demanda de insumos externos(2) adaptado al Bosque Tropical seco y húmedo. A pesar de la gran disponibilidad de recursos forrajeros, el sistema enfrenta importantes limitaciones forrajeras durante los periodos $\operatorname{secos}(11)$. Aunque es un modelo que busca el equilibrio con los recursos del agrosistema, se sitúa en zonas marginales y deprimidas económicamente y las explotaciones actúan como motor de desarrollo endógeno, generador de empleo y conservador activo de la biodiversidad(12).

La actividad agrícola se orienta desde una agricultura comercial de maíz (Zea mays) y arroz (Oryza sativa) a cultivos tropicales como el banano, (Musa paradisiaca) y palma africana (Elaeis guineensis), principalmente.

La explotación tipo dispone de 44 ha, 16 vacas criollo x cebú y una producción diaria por explotación de 51.9 L; valor inferior a los reportados en ganadería de doble propósito en
Stage 4. Collection of information. Case of Manabí.

The Manabí province is located in the Ecuadorian coast with an area of $19,364 \mathrm{~km}^{2}$. It extends on both sides of the equator, of $0^{\circ} 25^{\prime} \mathrm{N}$ to $1^{\circ}$ $57 \mathrm{~S}$, and $79^{\circ} 24^{\prime} \mathrm{W}$ to $80^{\circ} 55^{\prime} \mathrm{W}$. Two agroecological zones are distinguished: 1) Dry tropical forest, characterized by heights up to $300 \mathrm{~m}$, average annual temperature between 23 to $25^{\circ} \mathrm{C}$, periods of rain from December to May of 1,000 to $2,000 \mathrm{~mm}$ and dry season from J une to November; and 2) Tropical humid forest, with heights of 5 to $600 \mathrm{~m}$ asl, annual average temperatures of 23 to $25.5^{\circ} \mathrm{C}$, annual rainfall of 2,000 to $3,000 \mathrm{~mm}$, with a less rainy period from December to February(2).

A design of random sampling stratified by agroecological zone with proportional allocation(10) was used. Forty one (41) farms were studied what amounts to $3 \%$ of the population. Information about technologies was obtained by visits to farms and on-site interviews by the same technician, during 2012.

\section{Stage 5. Data analysis}

Initially, an inventory of technologies was conducted and the level of use of the six TP was quantified. The degree of association between the TP using the Spearman correlation coefficients was subsequently determined. The explanation of the variation of productive outcomes as a result of the use of the TP by stepwise multiple regression(8) was also offered in deep.

Stage 6. Technology strategy. Challenges for the future

The use of technologies and the reasons for their success and failure were analyzed. Later, according to the internal and external environment of the farm, and the analysis of the technologies identified, an operational proposal of technologies to improve the competitive positioning of farms has been provided(8). 
Perú(11), Costa Rica(13), Venezuela $(6,10,14)$ y Colombia(15). El $95 \%$ de los productores son propietarios, condición que favorece la adopción de tecnología. El productor tiene 52 años, casado, cuatro hijos o más y 23 años de experiencia en la actividad, la que se considera elevada al compararse con los 15.6 años reportada en doble propósito $(4,7,10)$.

Implementación de tecnologías

El promedio general de tecnologías incorporadas por explotación fue de $11 \pm 3$ con un rango entre 5 y 17 tecnologías. Los valores más altos en el uso de los PT fueron para salud animal, uso de la tierra y alimentación, en tanto el valor más bajo correspondió a equipos (Cuadro $1)$.

Al comparar ambas zonas se observa mayor nivel tecnológico en el Bosque húmedo tropical (BHT) en los PT de salud animal, alimentación y uso de la tierra (Figura 2), en donde predomina la actividad agrícola, en tanto que la ganadera es secundaria, con menor dimensión (13 vacas y $36 \mathrm{ha}$ ), menor productividad lechera (3.1 L/d) y carga ganadera por hectárea de 1.4 unidades de ganado mayor (UGM). Por el contrario, en el Bosque seco tropical (BST) el nivel de adopción tecnológica global es menor. El sistema del BST aglutina a las explotaciones de mayor dimensión (20 vacas y 53 ha), productividad lechera ( $3.5 \mathrm{~L} / \mathrm{d}$ ) y carga ganadera

\section{RESULTS AND DISCUSION}

Catlle in the coast responds to a mixed system of agriculture with dual purpose livestock characterized by a low demand from external inputs(2) adapted to the humid and dry tropical forest. Despite the wide availability of forage resources, the system faces significant forage constraints during the dry periods(11). Although it is a model that seeks to balance the agro system resources, it is located in economically depressed areas at marginal and deprived holdings where the farms act as a motor of endogenous development, generator of employment and active preservator of biodiversity(12).

Agricultural activity is driven from a commercial farming of corn (Zea mays) and rice (Oryza sativa) to tropical crops as banana, (Musa paradisiaca) and African oil palm (Elaeis guineensis), mainly.

The standard holding has 44 ha, 16 criollo $x$ Zebu cows and a daily production by farm of $51.9 \mathrm{~L}$; showing less value than those reported in dual-purpose catlle in Peru(11), Costa Rica(13), Venezuela $(6,10,14)$ and Colombia(15). Land is owned by $95 \%$ of producers, condition that favors the adoption of technology. The producer is $52 \mathrm{yr}$ old, married, with four children or more and $23 \mathrm{yr}$ of experience in the activity, considered high when compared with the 15.6 yr reported in dual purpose by others $(4,7,10)$.

Cuadro1. Adopción de los paquetes tecnológicos

Table 1. Implementation of technological packages

\begin{tabular}{lcccc}
\hline Technological & Technologies & \multicolumn{3}{c}{ Implementation (\%) } \\
\cline { 3 - 5 } package & $(\mathrm{n})$ & General & Dry forest & Humid forest \\
\hline PT1. Feeding & 4 & 55.5 & 53.7 & 57.1 \\
PT2. Equipment & 4 & 23.2 & 22.5 & 23.8 \\
PT3. Management & 4 & 28.0 & 22.5 & 33.3 \\
PT4. Land use & 5 & 55.6 & 61.0 & 50.5 \\
PT5. Reproduction & 4 & 28.6 & 27.5 & 29.8 \\
PT6. Health & 4 & 76.2 & $66.2^{\mathrm{a}}$ & $85.7 \mathrm{~b}$ \\
\hline
\end{tabular}

ab Values with different superscript, differ $(P<0.05)$. 
(4.5 UGM/ha) que se orientan fundamentalmente a la producción ganadera. En el BST destaca el PT uso de la tierra, donde se utiliza la tecnología de cercas para hacer lotes e incrementar la carga, y se corresponde con un sistema mixto carne-leche. Resultados similares se reportan en la ganadería de doble propósito de México(4,7).

Las correlaciones de Spearman mostraron alta asociación $(P<0.01)$ entre el PT de alimentación con el de equipos (0.711) y con el de reproducción (0.774). Asimismo, el PT de equipos se asoció débilmente con el de reproducción (0.398). La asociación entre el PT de reproducción y el de alimentación, indican que a medida que se mejora la alimentación, se obtiene mejor respuesta en el desempeño reproductivo.

La innovación organizativa y la implementación de nuevas tecnologías no deberían considerarse de modo aislado en el entorno de la explotación. Por el contrario, se evidencia un predominio de las interacciones positivas entre los PT, por lo que la implantación de nuevas tecnologías demanda el rediseño de los procesos para alcanzar las eficiencias que estas tecnologías ofrecen. La innovación tiene varios aspectos, entre ellos su carácter no lineal; es un proceso interactivo y colectivo que requiere de un abordaje sistémico(16). En todos los casos el proceso de innovación necesita la conjugación de todos los factores involucrados. Finalmente no se descarta la existencia de otras asociaciones de interés, como las compensaciones y sinergias entre las incertidumbres sociales, económicas y políticas $(3,4,7,16)$.

Los resultados de la regresión múltiple complementan los obtenidos con las correlaciones. La variabilidad de la producción, en el modelo general, es explicada en un $14 \%$ por el PT de salud animal. En BST las variaciones son de un $31 \%$, explicada por el PT de uso de la tierra. Por el contrario, en $\mathrm{BHT}$ el modelo explicó hasta el $30 \%$ de variabilidad debido al PT de salud
Figura 2. Paquetes tecnológicos según la zona agroecológica

Figure 2. Technological packages according to the agro ecological area

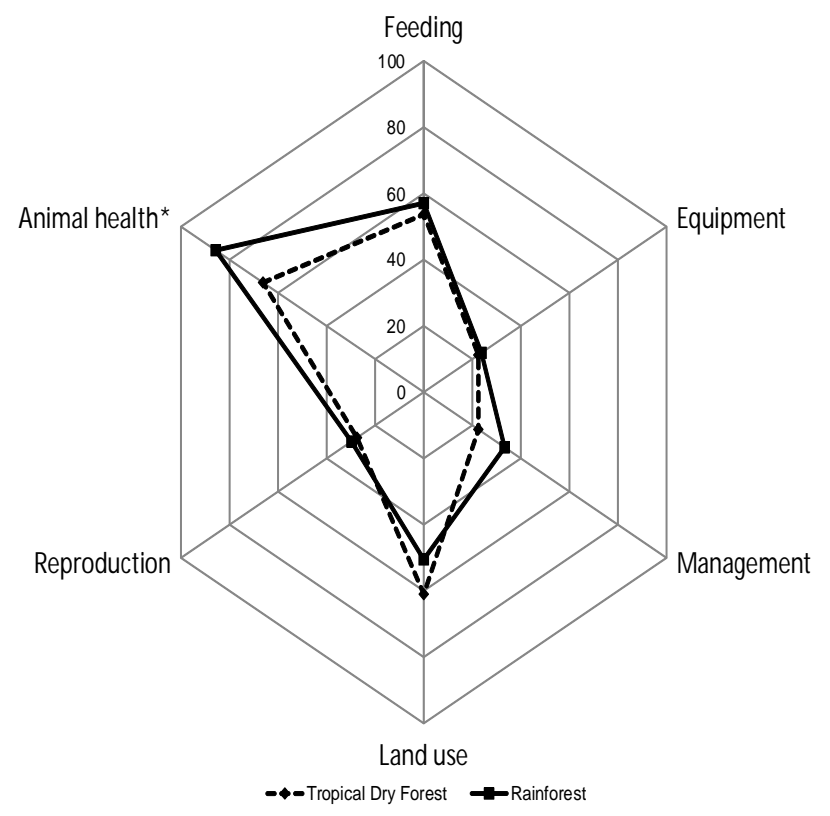

Technology implementation

General technologies incorporated per farm averaged $11 \pm 3$ with a range between 5 and 17 technologies. The highest values in the use of the TP were for animal health, use of land and feeding, while the lowest value corresponded to equipment (Table 1).

When comparing both areas, a higher technological level is shown in the tropical humid forest (THF) on the TP of animal health, food and land use (Figure 2); predominates agricultural activity, while the livestock is secondary, with smaller size ( 13 cows and 36 ha), lower dairy productivity $(3.1 \mathrm{~L} / \mathrm{d})$ and stocking rate per hectare of 1.4 animal units (AU). On the contrary, in the dry tropical forest (DTF) there is a minor level of global adoption of technology; system that brings together larger farms ( 20 cows and 53 ha), dairy productivity (3.5 L/d) and stocking density ( $4.5 \mathrm{AU} / \mathrm{ha}$ ) which are primarily oriented to livestock production. DTF is the TP land use, where technology fences 
Cuadro 2. Efecto de los paquetes tecnológicos

Table 2. Effect of technological packages

\begin{tabular}{|c|c|c|c|c|c|c|}
\hline \multirow[b]{3}{*}{ Variable } & \multicolumn{6}{|c|}{ Regresion model for Tropical Forest } \\
\hline & \multicolumn{2}{|c|}{ General } & \multicolumn{2}{|c|}{ Dry } & \multicolumn{2}{|c|}{ Humid } \\
\hline & $\bar{\beta}$ & $P$ & $\bar{\beta}$ & $P$ & $\bar{\beta}$ & $\bar{P}$ \\
\hline Constant & 9.224 & 0.732 & 155.0 & 0.000 & -13.852 & 0.675 \\
\hline $\mathrm{TP}_{1}$. Feeding & * & & * & & * & \\
\hline $\mathrm{TP}_{2}$. Equipment & * & & * & & * & \\
\hline $\mathrm{TP}_{3}$. Management & * & & * & & * & \\
\hline $\mathrm{TP}_{4}$. Land use & * & & -0.581 & 0.006 & * & \\
\hline $\mathrm{TP}_{5}$. Reproduction & * & & * & & * & \\
\hline $\mathrm{TP}_{6}$. Health & 0.402 & 0.009 & * & & 0.593 & 0.006 \\
\hline $\mathrm{R}^{2}$ & 0.140 & 0.315 & 0.302 & & & \\
\hline$P$ & 0.009 & 0.006 & 0.006 & & & \\
\hline
\end{tabular}

* Excluded variables.

animal, resultado similar al obtenido en el modelo general (Cuadro 2).

Estrategia tecnológica y retos en el futuro

Una vez que se establece la relación y asociación entre los PT se presentan algunas propuestas operativas para enfrentar los desafíos identificados (Cuadro 3).

\section{PT. Alimentación}

En el $24 \%$ de las explotaciones se suplementa a las vacas durante la lactancia, sólo el $7 \%$ suplementa la recría y el 90 \% usa algún subproducto como suplemento. No obstante en todas las explotaciones se administra complemento mineral a los animales.

La producción mixta combina la ganadería con agricultura de cosecha, por lo que existe un gran potencial en la utilización de subproductos de cultivos y residuos agrícolas de las industrias de acuerdo a la disponibilidad(2). El reto es profundizar en la caracterización de los subproductos, la conservación(17), elaboración de raciones balanceadas según los niveles de producción, las etapas fisiológicas del animal y los ciclos de los diferentes cultivos. are used to make lots and increase the load, and it corresponds to a meat-milk mixed system. Similar results are reported in the dual-purpose catlle of Mexico(4.7).

Spearman correlations showed high association $(P<0.01)$ between the TP in feeding with the equipment (0.711) and reproduction (0.774). Also the TPs equipment was weakly associated with reproduction (0.398). The association between the TP of reproduction and feeding, indicates that as the feeding is improved, a better response is obtained in reproductive performance.

Organizational innovation and the implementation of new technologies should not be viewed isolated in the neighborhood of the farm. By contrast, a predominance of positive interactions between the TPs is evident, so the introduction of new technologies demand the redesign of processes to achieve efficiencies that these technologies offer. Innovation has several aspects, including its non-linear character; it is a collective and interactive process that requires a systemic approach(16). In all cases the innovation process needs the combination of all the factors involved. Finally it does not rule out the existence of other 
PT. Equipos

Las explotaciones han adoptado mejoras en un $39 \%$ de los casos; en tanto que la mayor parte no ha acometido reformas estructurales en los dos últimos años. Existen instalaciones básicas para la cría de ganado: corrales, bebederos y manga, un $56 \%$ dispone de dos corrales y tan sólo un $24.4 \%$ cuenta con tres o más corrales de manejo. La existencia de corrales es una herramienta primordial a la hora de planificar actividades de manejo i.e: alimentación, reproducción.

Las explotaciones no disponen de una zona adecuada para el ordeño: el $77 \%$ no disponen de piso firme en el corral, la ventilación es deficiente y carecen de condiciones higiénicas sanitarias adecuadas. En el $100 \%$ de los casos el ordeño es manual y con el ternero al pie, condiciones que dificultan las prácticas correctas associations of interest, such as the trade-offs and synergies between social, economic and political uncertainties $(3,4,7,16)$.

The results of multiple regression complement those obtained with the correlations. For the variability of production, the general model is explained $14 \%$ by the TP of animal health. DTF variations are a $31 \%$ explained by the TP of land use. On the contrary, in HTF model explained up to $30 \%$ of variability due to the TP of animal health, results similar to that obtained in the general model (Table 2).

Technology strategy and challenges in the future

Once you set the relationship and association among the TPs, there are some operational proposals to the identified challenges (Table 3).

Cuadro 3. Estrategias de incorporación por paquetes tecnológicos

Table 3. Strategies for technological packages incorporation

\begin{tabular}{|c|c|c|}
\hline Technological package & Implementation & Challenge \\
\hline $\mathrm{TP}_{1}$. Feeding & $\begin{array}{l}\text { Minerals } \\
\text { Supplements } \\
\text { Subproducts }\end{array}$ & $\begin{array}{l}\text { Adequate diet } \\
\text { Maximize the use of crops by-products }\end{array}$ \\
\hline $\mathrm{TP}_{2}$. Equipment & $\begin{array}{l}\text { Infrastructure } \\
\text { Services (electricity, water, etc) }\end{array}$ & $\begin{array}{l}\text { Pens and fences } \\
\text { Milking area improvement }\end{array}$ \\
\hline $\mathrm{TP}_{3}$. Management & $\begin{array}{l}\text { Animal identification } \\
\text { Business management } \\
\text { Environmental management }\end{array}$ & $\begin{array}{l}\text { Use of records in decision-making } \\
\text { Integrated management plan } \\
\text { Encourage association }\end{array}$ \\
\hline $\mathrm{TP}_{4}$. Land use & $\begin{array}{l}\text { Grazing } \\
\text { Farming-agriculture system } \\
\text { Fences }\end{array}$ & $\begin{array}{l}\text { Better grazing strategies } \\
\text { Environmental practices } \\
\text { Cultivated pastures, forages reserves, } \\
\text { sustainable soil and water management }\end{array}$ \\
\hline $\mathrm{TP}_{5}$. Reproduction & $\begin{array}{l}\text { Natural mating } \\
\text { Artificial insemination }\end{array}$ & $\begin{array}{l}\text { Implementation of a breeding program } \\
\text { Program of selection and genetic improvement }\end{array}$ \\
\hline $\mathrm{TP}_{6}$. Health & Mandatory preventive plan & $\begin{array}{l}\text { Health plan according to the } \\
\text { epidemiology of the farm } \\
\text { Program of good farming practices }\end{array}$ \\
\hline
\end{tabular}


de higiene y limpieza; caso del lavado de manos, de pezones, retirada del estiércol del área de ordeño, etc. Se mantiene el becerro para facilitar el descenso de la leche y el destete coincide en gran parte de los casos con el final de la lactancia. No es frecuente el uso de tanques de refrigeración para la leche aunque existen centros de acopio y enfriamiento de la leche.

El uso de la tecnología se asocia inicialmente a la mejora de las instalaciones de manejo y área de ordeño, que permitan durante el ordeño, almacenamiento y despacho de la leche, garantizar la higiene y limpieza a fin de mantener la calidad higiénico sanitaria del producto(18).

\section{PT. Gestión}

La mayor parte de la producción se destina a la producción artesanal de quesos (63.4\%), otra parte a la venta de leche líquida (23.1\%) y otra al autoconsumo por parte de la familia y los terneros (13.5\%).

Se observaron mejoras en la planificación de los procesos, fundamentalmente en las áreas de gestión comercial aunque de manera independiente ( $51 \%$ ), orientada a la búsqueda de mejor precio de venta de los diferentes productos. El $41 \%$ de las explotaciones se apoyan en las cooperativas para la toma de decisiones en el manejo de la explotación. El uso de identificación animal y registros se observa en el $10 \%$ de los casos.

Se plantea como reto la utilización de la información y los registros productivos en la toma de decisiones. La identificación y registros individuales permiten un seguimiento reproductivo y productivo por vaca, lo que favorece el resultado de la explotación y el desempeño reproductivo $(19,20,21)$. Por otro lado, abordar los retos de las tecnologías de gestión (Cuadro 3) permitirá a los productores avanzar en el diseño estratégico de la explotación con un enfoque innovador y competitivo $(3,16)$, ajustado al sistema, lo que es factible ya que el $95 \%$ de los productores son propietarios de

\section{TP. Feeding}

In $24 \%$ of the farms cows are supplemented during lactation, only $7 \%$ supplements calves and $90 \%$ uses any by-product as supplement. However, mineral supplement is administered to animals in all farms.

Mixed production combines farming with agriculture harvest, so there is a great potential in the use of crops by-products and agricultural waste from the industries according to the availability(2). The challenge is to deepen characterization of by-products, preservation(17), elaboration of balanced rations according to production levels, the physiological stages of the animal and the cycles of different crops.

\section{TP. Equipment}

Farms have adopted improvements in $39 \%$ of cases; while the majority has not undertaken structural reforms in the past two years. There are basic facilities for livestock: pens, drinkers and chute, $56 \%$ have two pens and only $24.4 \%$ have three or more pens for management. The existence of pens is a primary tool when planning management i.e: feeding, reproduction.

The farms do not count on with a suitable milking area: $77 \%$ have no firm pen floor, ventilation is poor and lack of adequate sanitary hygienic conditions. In a $100 \%$ of cases milking is done by hand and with the calf at foot, conditions that impair good practices of hygiene and cleanliness, as hand and nipples washing, removal of manure from the milking area, etc. The calf is maintained to facilitate milk letdown and weaning in the cases of matches the end of lactation. The use of milk cooling tanks is not common although there are centers for the collection and milk cooling.

The use of the technology is initially associated with the improvement of the management and milking area, allowing during milking, storage and delivery of milk, ensure hygiene and cleaning to maintain the hygienic-sanitary quality of the product(18). 
la explotación, condición sine qua non para el desarrollo de mejoras.

PT. Uso de la tierra

En el $80 \%$ de las explotaciones se desarrolla actividad agrícola y en el $68 \%$ se destina a la alimentación animal. Asimismo el $88 \%$ emplea algún tipo de fertilizante orgánico o químico. Las explotaciones utilizan el pastoreo como base de la alimentación: el $63 \%$ lo realizan guiado o conducido, en tanto que las restantes lo hacen en cercas. Respecto a la zona climática aparecen diferencias significativas, con un $26.8 \%$ de explotaciones BST que realiza pastoreo en cercas frente a las BHT donde mayoritariamente es guiado.

La innovación tecnológica debe orientarse, en primer lugar, a la utilización de cercas y técnicas como pastoreo rotacional, que permitan el uso racional de los recursos y el mantenimiento de la carga $(22,23)$. Por otra parte, es necesaria la aplicación del conocimiento ecológico en la mejora de la gestión sostenible del pastizal; i.e. profundizar en el uso de pasturas cultivadas a base de pasto Guinea (Panicum maximun), estrella (Cynodon plectostachum, Cyodon nlenfuensis), maralfalfa (Pennisetum spp.) y otros como el kingrass (Pennisetum purpureum $x$ Pennisetum typhoides), braquiarias (Brachiaria decumbens) y pasto alemán (Echinochloa polystachia). Finalmente, es necesario el desarrollo de tecnologías que favorezcan la elaboración y utilización de reservas forrajeras durante la época de mayor producción de biomasa forrajera(23). Así como la posibilidad de incorporar esquemas silvopastoriles que permitan aprovechar el recurso forestal presente(24).

\section{PT. Reproducción}

El grupo racial predominante es la cruza de criollo con cebú (70.5\%), aunque son frecuentes los cruces con Brahman, Charolais y Holstein; se utiliza inseminación artificial en el $8 \%$ de los casos. El $90 \%$ de las explotaciones hacen revisiones postparto como manejo
TP. Production and commercialization

Most of the production goes to the artisanal production of cheeses $(63.4 \%)$, another part goes to the sale of liquid milk (23.1\%) and another one for self-consumption by the family and calves (13.5\%).

Improvements were observed in planning processes, primary in the areas of business management but in independent way (51 \%), oriented to the pursuit of better selling price of the different products. Farms rely on cooperatives to the decision-making in the management of the farm (41 \%). The use of animal identification and registration is observed in $10 \%$ of cases.

The use of the information and production records in the decision-making process arises as a challenge. Identification and individual records allow a reproductive and productive follow-up per cow, which favors the operational result and reproductive performance $(19,20,21)$. On the other hand, address the challenges of management technologies (Table 3), will allow producers to advance in strategic farm design with an innovative and competitive approach $(3,16)$, adjusted to the system, what is feasible because $95 \%$ of the producers are the owners of the land, condition sine qua non for the development of improvements.

\section{TP. Land use}

In $80 \%$ of the farms agricultural activity is developed and in $68 \%$ goes for animal feed. In addition, $88 \%$ uses some type of chemical or organic fertilizer. Grazing is used as the base for feeding: $63 \%$ conduct it guided or led, while the remaining ones do it with fences. At this respect there are significant differences according to the climate, with a $26.8 \%$ of farms DTF performing grazing with fences against the HTF where mostly is guided.

Technological innovation must aim, first of all, the use of fences and techniques such as rotational grazing that allows the rational use 
reproductivo, y sólo el $7 \%$ incorpora a las novillas en un programa de manejo reproductivo a fin de acortar el período de recría. El objetivo reproductivo propuesto por los ganaderos es un parto al año aunque los resultados muestran un intervalo entre parto mayor a 400 días. La edad de primera cubrición de las novillas es superior a los 22 meses y el peso al nacimiento de los terneros es inferior a los $26 \mathrm{~kg}$. Estos datos indican que la reproducción se ajusta a las condiciones naturales del sistema, frente al objetivo reproductivo y a la utilización de tecnologías reproductivas.

El reto tecnológico consiste en la implantación de un programa reproductivo integral, cuya meta sea la mejora de la eficiencia de acuerdo a los objetivos, la raza, el sistema productivo y las condicionantes de la zona(3). Uno de los factores determinantes del éxito en el uso de nuevas tecnologías reproductivas es su armonización con las restantes áreas de la empresa: alimentación, gestión, instalaciones y uso de la tierra $(3,16)$. A largo plazo se sugiere incorporar un programa de selección y mejoramiento genético con una adecuada gestión del recuso genético de la explotación(25).

\section{PT. Salud animal}

El plan sanitario que se aplica es básico y se circunscribe generalmente a los programas de profilaxis y control de las enfermedades de declaración obligatoria: aftosa, estomatitis vesicular y rabia bovina. Aunque también es frecuente el control de enfermedades de la zona: leptospirosis, brucelosis, etc. Dentro del uso de tecnologías orientadas a la reducción de riesgos destaca el control de parásitos (95\%) con una frecuencia de dos veces al año, la prevención de enfermedades infecto contagiosas como aftosa (100\%), carbunco (61 \%) y otras (24\%), con resultados similares a los descritos en Ecuador(2).

La implantación de un Programa de buenas prácticas ganaderas que incorpore aspectos sencillos como es la higiene y limpieza de los operarios, de las áreas y equipos y efectúe análisis rutinarios de leche en tanque, supondrá of resources and the maintenance of the stocking rate $(22,23)$. On the other hand, it is required the application of ecological knowledge in the sustainable management of grassland improvement; i.e. deepen the use of cultivated pastures based on Guinea grass (Panicum maximum), stargrass (Cynodon plectostachum, Cyodon nlenfuensis), maralfalfa grass (Pennisetum spp) and others such as the kingrass (Pennisetum purpureum $x$ Pennisetum typhoides), braquiarias (Brachiaria decumbens) and German grass (Echinochloa polystachia). Finally, the implementation of technologies that promote the development and use of forage reserves during the period of increased production of forage biomass is needed(23). As well as the possibility of incorporating silvopastoral schemes enabled to take advantage of the present forest resource(24).

\section{TP Reproduction}

The predominant breed group is the Creole with Zebu cross $(70.5 \%)$, but crossings with Brahman, Charolaise and Holstein are frequent. Artificial insemination is used in $8 \%$ of the cases, and $90 \%$ of the farms do postpartum reviews as reproductive management, and only $7 \%$ joined the heifers in a reproductive management program in order to shorten the rearing period. The reproductive goal proposed by farmers aim to achive a calving each year, although the results show a calving interval of more than $400 \mathrm{~d}$. The age of first mating of heifers is greater than $22 \mathrm{mo}$ and calves birth weight is less than the $26 \mathrm{~kg}$. These data indicate that reproduction is adjusted to the natural conditions of the system, against the reproductive goals and the use of reproductive technologies.

The technological challenge is the implementation of a comprehensive breeding program, whose goal is the improvement of efficiency according to the objectives, the breed, the productive system and conditions in the area(3). One of the determinants of success in the use of new reproductive technologies is 
avances importantes en el campo de la salud animal y la mejora de la calidad higiénico sanitaria de la leche(26).

\section{CONCLUSIONES E IMPLICACIONES}

La metodología desarrollada facilita el inventario de tecnologías y la propuesta de paquetes tecnológicos en vacunos de doble propósito. El mayor nivel de implementación se concreta en los paquetes tecnológicos de alimentación, reproducción y salud animal; y su adopción responde a un proceso sistémico con interacciones dinámicas. Se plantea como reto tecnológico profundizar en la investigación aplicada de subproductos en la dieta, así como la utilización de la información y los registros en la toma de decisiones. La incorporación de innovaciones requiere un proceso interactivo en red, de acuerdo a los objetivos estratégicos y a la estructura organizativa de la explotación. El estudio confiere un carácter prospectivo que requiere de verificaciones posteriores que fortalezcan la identificación de innovaciones, y que permitan en un futuro su utilización como herramienta de toma de decisiones en distintas zonas tropicales de doble propósito.

\section{AGRADECIMIENTOS}

El estudio se ha desarrollado dentro del Proyecto "Modelos de innovación abierta en el sistema de doble propósito de Manabí (Ecuador)", financiado por el FOCICYT de la Universidad Técnica Estatal de Quevedo (Ecuador) y al Consejo de Desarrollo Científico y Humanístico de la Universidad Central de Venezuela (CDCHUCV), por la beca para la realización de los estudios de Doctorado en la Universidad de Córdoba, España.

\section{LITERATURA CITADA}

1. INEC. Instituto Nacional de Estadísticas y Censos. Encuesta de superficie y Producción Agropecuaria Continua (ESPAC). Informe Ejecutivo. Ecuador. 2012. their harmonization with the remaining areas of the farm: feeding, management, facilities and land use $(3,16)$. For the long-term, it is suggested to incorporate a program of selection and genetic improvement with a proper management of the genetic resource farm(25).

\section{TP Animal health}

The health plan that applies is basic, and is usually confined to programs of prophylaxis and control of reportable diseases: foot and mouth disease, vesicular stomatitis, bovine rabies; although it is also frequent the control of prevalent diseases in the area, as leptospirosis, brucellosis, etc. Within the use of technologies aimed at reducing risks, the control of parasites is highlighted (95\%) with a frequency of two times a year, the prevention of infectious contagious diseases as foot and mouth disease (100\%), anthrax (61 \%) and other (24\%), with results similar to those described in Ecuador(2).

Implementing a program of good farming practices that incorporate simple aspects such as hygiene and cleaning of operators, areas and equipment; and also carry out routine milk testing in the tank, will mean important progress in animal health and improvement of the hygienic-sanitary milk quality(26).

\section{CONCLUSIONS AND IMPLICATIONS}

The developed methodology facilitates the inventory of technologies and the proposal of technological packages in dual purpose cattle. The highest level of implementation focuses on the technological packages of feeding, breeding and animal health; and its adoption is a systemic process with dynamic interactions. It arises as a technological challenge, deepen in the applied research of by-products in the diet, as well as the use of the information and records in the decision-making. The incorporation of innovations require an interactive process in network, according to the strategic objectives and the organizational structure of the holding. The study gives a prospective character requiring 
2. Requelme N, Bonifaz N. Caracterización de sistemas de producción lechera de Ecuador. Universidad Politécnica Salesiana, Ecuador. Rev La Granja 2012;15(1):55-69.

3. González-Stagnaro C, Madrid-Bury N. Logros del benchmarking en el incremento de la eficiencia reproductiva, producción de leche e ingresos económicos en rebaños tradicionales. In: C González-Stagnaro, N Madrid-Bury, E Soto-Belloso editores. Innovación \& Tecnología en la Ganadería de Doble Propósito. Maracaibo, Venezuela: Ediciones Astro Data S.A. 2011; 730-748.

4. Cuevas-Reyes V, Baca del Moral J, Cervantes-Escoto F, Espinosa-García J, Aguilar-Ávila J, Loaiza-Meza A. Factores que determinan el uso de innovaciones tecnológicas en la ganadería de doble propósito en Sinaloa. México. Rev Mex Cienc Mex 2013;4(1):31-46.

5. de Janvry A, Dunstan A, Sadoulet E. Recent advances in impact analysis methods for ex-post impact assessments of agricultural technology. Options for the CGIAR. Workshop: Increasing the rigor of ex-post impact assessment of agricultural research: A discussion on estimating treatment effects. Consultative Group on International Agricultural Research. California, USA. 2011:40.

6. Urdaneta F, Peña ME, Rincón R, Romero J, Rendón-Ortín J. Gestión y tecnología en sistemas ganaderos de doble propósito (Taurus-Indicus). Rev Cient FCV-LUZ 2008; XVIII(6): 715-724.

7. Salas-Gonzáleza JM, Leos-Rodrígueza JA, SagarnagaVillegasa LM, Zavala-Pineda MJ. Adopción de tecnologías por productores beneficiarios del programa de estímulos a la productividad ganadera (PROGAN) en México. Rev Mex Cienc Pec 2013;4(2):243-254.

8. García A, Rivas J. Adopción de tecnología en la ganadería de doble propósito en la costa ecuatoriana. Caso Manabí. Logros y Desafíos de la Ganadería de Doble Propósito. Maracaibo, Venezuela: Ediciones Astro Data S.A. [in press] 2014.

9. Urdaneta F, Materán M, Peña ME, Casanova A. Tipificación tecnológica del sistema de producción con ganadería de doble propósito (Bos taurus $\times$ Bos indicus). Rev Cient FCVLUZ 2004; XIV(3):254-262.

10. Velasco-Fuenmayor J, Ortega-Soto L, Sánchez-Camarillo E, Urdaneta F. Factores que influyen en nivel tecnológico en las fincas ganaderas de doble propósito localizadas en el estado Zulia, Venezuela. Rev Cient FCV-LUZ 2009; XIX(2): 187-195.

11. Holmann F, Rivas L, Carulla J, Rivera B, Giraldo L, Guzmán S, Martínez M, Medina A, Farrow A. Evolución de los sistemas de producción de leche en el trópico latinoamericano y su interrelación con los mercados: Un análisis del caso colombiano. Centro Internacional de Agricultura Tropical (CIAT), International Livestock Research Institute (ILRI) and Systemwide Livestock Program (SLP). 2006. http:// webapp.ciat.cgiar.org/tropileche/articulos. pdf. Consultado 15 Ene, 2014.

12. Hemme T, García O, Khan A. Estudio de la producción de leche en Bangladesh con atención especial a los pequeños productores. En: Food and Agriculture Organization of the United Nations editor. Iniciativa de políticas pecuarias en favor de los pobres (PPLPI). 2013. http://www.fao.org/ag/ pplpi.pdf. Consultado 15 Ene, 2014.

13. Estrada R, Holmann F. Competitividad de la producción de leche frente a los tratados de libre comercio en Nicaragua, subsequent verifications to strengthen the identification of innovations, and allowing in the future their use as a tool for decision making in various tropical areas for dual purpose catlle.

\section{ACKNOWLEDGMENTS}

The study has been developed within the project "Models of open innovation in the system of dual purpose of Manabi (Ecuador)", funded by the FOCICYT of the State Technical University of Quevedo (Ecuador) and the Council of scientific development and humanistic of the Universidad Central of Venezuela (CDCH-UCV), by the grant for the realization of the doctoral studies in the University of Cordoba, Spain.

End of english version

Costa Rica y Colombia Centro Internacional de Agricultura Tropical (CIAT). Internacional Livestock Research Institute (ILRI). Cali, Colombia. CIAT 2008.

14. Velasco-Fuenmayor J, Ortega-Soto L, Urdaneta F, SánchezCamarillo E. Relación entre el nivel de tecnología y los índices de productividad en fincas ganaderas de doble propósito localizadas en la cuenca del lago de Maracaibo. Rev Cient FCV-LUZ 2009; XIX(1):84-92.

15. Botero A, De la Ossa V. Estudio de caso: Un sistema de producción con enfoque agroecológico, Departamento del Magdalena, Colombia. Rev Colombiana Cienc Anim 2010;2(1):225-241.

16. De Pablos-Heredero C, López-Berzosa D. Open innovation at firms and public administrations: technologies for value creation. Hershey, USA: IGI Global; 2011.

17. Roca Al. Sistemas sostenibles de producción de leche en zonas húmedas con utilización de recursos de la explotación [tesis de doctorado]. Santiago de Compostela, España. Universidad de Santiago de Compostela. Escuela Politécnica Superior; 2011.

18. Fröberg S, Aspegren-Güldorff A, Olsson I, Marin B, Berg C, Hernandez $C$, et al. Effect of restricted suckling on milk yield, milk composition and udder health in cows and behaviour and weight gain in calves, in dual-purpose cattle in the tropics. Trop Anim Health Prod 2007;39:71-81.

19. Silva D, Peña ME, Urdaneta F. Registros de control e indicadores de resultados en ganadería de doble propósito. Rev Cient FCV-LUZ 2004; XX(1):89-100.

20. Madouasse A, Huxley JN, Browne WJ, Bradley AJ, Dryden IL, Green MJ. Use of individual cow milk recording data at the start of lactation to predict the calving to conception interval. J Dairy Sci 2010;93:4677-4690. 


\section{IDENTIFICACIÓN E IMPLEMENTACIÓN DE PAQUETES TECNOLÓGICOS EN GANADERÍA VACUNA}

21. Villasmil-Ontivero $Y$, Roman-Bravo R. Identificación animal y registros ganaderos. In: C. González-Stagnaro, E. SotoBelloso editores. Manual de Ganadería Doble Propósito. Maracaibo, Venezuela: Ediciones Astro Data S.A. 2005. 140-143.

22. Holmann F, Argel P, Pérez E. Impacto de la adopción de forrajes mejorados en fincas de pequeños productores en Centroamérica. Análisis expost. Cali, Colombia. Centro Internacional de Agricultura Tropical (CIAT). International Livestock Research Institute (ILRI) 2008.

23. Betancourt M, Caraballo A. Henificación y ensilaje: aspectos operativos y tecnológicos. In: C. González-Stagnaro, E. SotoBelloso editores. Manual de Ganadería Doble Propósito.
Maracaibo, Venezuela: Ediciones Astro Data S.A. 2005:183187.

24. Calle Z, Murgueitio E, Chará J. Integración de las actividades forestales con la ganadería extensiva sostenible y la restauración del paisaje. Unasylva 2012; 239(63):31-40. http://www.fao.org/ docrep/017/i2890s/i2890s06.pdf Consultado 15 Ene, 2014.

25. Pariacote F, Chirinos Z, Zambrano R. Gestión de recursos genéticos en un rebaño bovino tipo de doble propósito de la región de Perijá, Venezuela. AICA 2012;2:137-141

26. Molina A, Yamaki $M$, Berruga MI, Althaus RL, Molina P. Management and sanitary practices in ewe dairy farms and bulk milk somatic cell count. Spanish J Agric Res 2010;8(2):334-341.

\section{Anexo 1. Paquetes Tecnológicos}

\section{Annex 1. Technological packages}

Feeding: Technologies that identify and optimize the feeding system (maximum production - efficient use of inputs)

1.- Supplements during the prepartum; type of supplement

2.- Supplements during milking, type of supplement and time of delivery

3.- It makes use of by-products, application form, and by-products type

4.- Incorporates the use of minerals; presentation.

Equipment: Technologies that maximize the use of the infrastructure and human resource without prejudice to animal and environmental well-being

1.- Installations in good conditions and number according to the size of the herd, operational and secure

2.- Milking area and cow-calf operations appropriate to the size of the herd, operational and easy hygiene and maintenance

3.- Services available: electricity, drinking water, communications

4.- Infrastructure for waste management

Management: Technologies that allow to get data, process and generate strategies for operational improvement

1.- Individual identification, or implementation considered important

2.- System of records of events (births, deaths, sales, breeding, etc.) or its incorporation considered important

3.- It belongs to an Association that will support his management activity

4.- Commercial management of products

Land use: Technologies that maximize the exploitation of natural pastures, naturalized, crop residues, through the production of food and its processing (silage or hay) and the development of the agricultural activity

1.- Take advantage of the natural resource using grazing; which type of grazing uses

2.- It has an area for agricultural use; agriculture is used for food production

3.- Make agriculture as an activity of commercial interest

4.- Set grazing management strategies (i.e: stocking, rotational, deferred grazing, fences, etc.)

5.- Use of chemical or organic fertilizers applied in agriculture

Health: Technologies that allow to mitigate the risks associated with changes in the animal health, and enhance and guarantee the quality of the products

1.- Performs the basic health plan: health status and disease prevention program

2.- It includes the control of internal and external parasites in the herd

3.- It includes the prevention of other diseases according to the epidemiology of the farm

4.- It executes the plan of hygiene (insect and rat control) and disinfection of all areas 
